\title{
Standar Penanganan Pinjaman Bermasalah Pada Koperasi Kredit Himpunan Usaha Bersama Desa Cintamanis Baru Kecamatan Air Kumbang Kabupaten Banyuasin
}

\author{
Oktariansyah $^{1}$, Edduar Hendri ${ }^{2}$, Muhamad Sopian Yuliandi ${ }^{3}$, Dwi Hanadya ${ }^{4}$ \\ ${ }^{1}$ Fakultas Ekonomi dan Bisnis Universitas PGRI Palembang, rianbro82@univpgri-palembang.ac.id \\ ${ }^{2}$ Fakultas Ekonomi dan Bisnis Universitas PGRI Palembang, hendri edduar@yahoo.com \\ ${ }^{3}$ Fakultas Ekonomi dan Bisnis Universitas PGRI Palembang, yandix92@gmail.com \\ ${ }^{4}$ Politeknik Darussalam Palembang, hanadya.dwi@gmail.com
}

\begin{abstract}
ABSTRAK
Tujuan penelitian ini adalah untuk mengetahui prosedur yang dilakukan Koperasi Kredit Himpunan Usaha Bersama dalam penanganan pinjaman bermasalah. Ruang lingkup penelitian ini mencakup diskripsi umum profil Koperasi Kredit Himpunan Usaha Bersama dan Standar penanganan pinjaman bermasalah pada Koperasi Kredit Himpunan Usaha Bersama. Metode pengumpulan data yang digunakan dalam penelitian ini meliputi wawancara langsung pegawai Koperasi Kredit Himpunan Usaha Bersama, studi pustaka yaitu pengumpulan data dari berbagai sumber literatur dan buku yang berhubungan dengan pinjaman. Metode pembahasan yang digunakan oleh peneliti adalah analisis diskriptif kualitatif yaitu pembahasan secara sistematis, faktual dan akurat mengenai suatu objek yang diteliti. Hasil dari penelitian ini adalah Standar Penanganan yang dilakukan koperasi Kredit Himpunan Usaha Bersama Desa Cinta Manis Baru Kecamatan Air Kumbang Kabupaten Banyuasin sudah cukup baik namun koperasi Kredit Himpunan Usaha Bersama tidak mengikuti prosedur sesuai SOM (Standar Operasional Manajemen). Tahap yang tidak ada yaitu pembinaan anggota. Padahal pembinaan anggota berfungsi sebagai pendekatan kepada anggota, hal ini dilakukan agar anggota yang mengalami kredit macet tetap mau berusaha Membayar hutangnya.
\end{abstract}

Kata Kunci: Prosedur Standar Penanganan Pinjaman Bermasalah.

\section{ABSTRACT}

The purpose of this study was to determine the procedures undertaken by the Joint Business Credit Unions in handling problem loans. The scope of this research includes a general description of the profile of the Joint Business Credit Cooperatives and the standard handling of problem loans in the Joint Business Credit Unions. Data collection methods used in this study include direct interviews of employees of the Joint Business Credit Cooperative, literature study, namely the collection of data from various sources of literature and books related to loans. The discussion method used by researchers is a qualitative descriptive analysis that is a systematic, factual and accurate discussion of an object under study. The results of this study are the Handling Standards conducted by the Cooperative Business Credit Cooperative of Cinta Manis Baru Subdistrict Air Kumbang Banyuasin District is good enough but the Cooperative Business Association Credit Cooperative does not follow procedures according to SOM (Management Operational Standards). The missing stage is member coaching. Though coaching members serves as an approach to members, this is done so that members who experience bad credit still want to try to pay their debts.

Kywords: Standard procedures for handling problem loans.

\section{A. PENDAHULUAN}

Lembaga keuangan memegang peran penting dalam perekonomian dewasa ini, hal ini disebabkan karena kebutuhan masyarakat yang semakin bertambah seiring perkembangan globalisasi. lembaga keuangan terdiri dari lembaga keuangan perbankan dan lembaga Keuangan non bank, salah satu contoh keuangan non bank yaitu koperasi. 
Dilihat dari asal katanya istilah koperasi berasal dari bahasa Inggris cooperation yang berarti usaha bersama. menurut pengertian "Koperasi" maka segala bentuk pekerjaan yang dilakukan secara bersama-sama sebenarnya dapat disebut sebagai koperasi. namun yang dimaksud dengan koperasi dalam hal ini bukanlah dalam arti sembarang bentuk kerjasama seperti itu. arti dari koperasi disini adalah suatu bentuk perusahaan yang didirikan oleh orangorang tertentu untuk melaksanakan kegiatan-kegiatan tertentu berdasarkan aturan-aturan dan tujuan tertentu pula.

Undang-undang Republik Indonesia. Nomor 25 tahun 1992 pasal 1 ayat 1 tentang perkoperasian dirumuskan bahwa "Koperasi adalah badan usaha yang beranggotakan orang atau badan hukum koperasi dengan melandaskan kegiatannya berdasarkan prinsip koperasi sekaligus sebagai gerakan ekonomi rakyat yang berdasar atas asas kekeluargaan". Dalam garis besarnya, Koperasi pada umumnya dipahami sebagai perkumpulan orang-orang yang secara sukarela mempersatukan diri untuk memperjuangkan peningkatan kesejahteraan ekonomi mereka, melalui pembentukan suatu perusahaan yang dikelola secara demokratis.

Di Indonesia terdapat berbagai macam koperasi. Pasal 16 Undang-undang Nomor 25 tahun 1992 tentang Perkoperasian disebutkan "Bahwa Setiap Koperasi Mencantumkan jenis koperasi dalam anggaran dasar, jenis koperasi yang dimaksud adalah didasarkan pada kesamaan kegiatan usaha dan/atau kepentingan ekonomi anggota" seperti antara lain Koperasi Simpan Pinjam, Koperasi Konsumen, Koperasi Produsen, Koperasi Pemasaran dan Koperasi Jasa. Khusus koperasi yang dibentuk oleh golongan fungsional seperti pegawai negeri, anggota ABRI, karyawan dan sebagainya, bukan merupakan koperasi tersendiri.

Salah satu jenis koperasi yaitu Koperasi Simpan Pinjam (KSP). Koperasi Simpan Pinjam termasuk dalam kelompok Lembaga Keuangan Mikro formal. Di Jerman pada pertengahan abad 19 Koperasi Simpan Pinjam Dikembangkan, hal ini disebabkan keperluan akan kebutuhan peminjaman uang tetapi dengan prosedur yang mudah dan cepat. Koperasi Simpan Pinjam tersebut berkembang di berbagai Negara karena keberhasilannya. Di Indonesia Koperasi Simpan Pinjam mulai diperkenalkan oleh pemerintah Belanda pada tahun 1895, yang berbentuk berbagai lembaga simpan pinjam. Peraturan yang mendukung adanya Koperasi Simpan Pinjam adalah Peraturan Pemerintah No. 9 tahun 1995 tentang Pelaksanaan Usaha Simpan Pinjam.

Koperasi simpan pinjam tidak lepas dari masalah kredit, demikian juga pada Koperasi Kredit Himpunan Usaha Bersama (KOPDITHUB) sebagai lembaga simpan pinjam harus mampu mengelola, menghimpun dan menyalurkan dana masyarakat secara efektif dan efisien agar meningkatkan taraf hidup bagi anggota khususnya dan masyarakat pada umumnya. yang dimaksud kredit/pinjaman bermasalah disini adalah keadaan dimana anggota sudah tidak sanggup membayar sebagian atau seluruh kewajibannya kepada Koperasi Kredit Himpunan Usaha Bersama seperti yang telah diperjanjikan dalam perjanjian kredit. penyaluran kredit kepada anggota besar resikonya, maka kredit memerlukan suatu sistem pengelolaan agar resiko kredit macet atau kerugian dapat diminimalisir.

Untuk meminimalisir terjadinya kredit macet maka Koperasi Kredit Himpunan Usaha Bersama memerlukan adanya manajemen kredit yang efektif sehingga dengan manajemen kredit tersebut dapat mencegah adanya kredit 
macet. Salah satu caranya yaitu dengan analisis 5C yang terdiri dari Character, Capacity Capital,Condition of Economic, dan Collateral. Analisis tersebut dilakukan sebelum pemberian kredit agar bagian Analisis Kredit dapat mengerti dan memahami mengenai debiturnya. Analisis seperti itu dilakukan agar Koperasi Kredit Himpunan Usaha Bersama dapat meminimalisasi adanya pinjaman bermasalah. Walaupun begitu adanya pinjaman bermasalah tak dapat dielakkan secara keseluruhan. tiap tahun tetap ada persentase anggota yang mengalami pinjaman bermasalah.

\section{B. KAJIAN TEORI}

\section{Pengertian Koperasi}

Pengertian Koperasi dalam Undang-undang pasal 1 bab 1 Tahun 1992 tentang perkoperasian bahwa Koperasi adalah badan usaha yang didirikan oleh orang perseorangan atau badan hukum koperasi dengan melandaskan kegiatannya berdasarkan perinsip Koperasi sekaligus sebagai gerakan ekonomi rakyat yang berdasarkan atas asas kekeluargaan.

\section{Pengertian Pinjaman/Kredit}

Berdasarkan Undang-Undang Nomor 10 Tahun 1998 tentang Pokok-Pokok Perbankan, yang dimaksud dengan pinjaman/kredit adalah "Penyediaan uang atau tagihan-tagihan yang dapat disamakan dengan itu berdasarkan persetujuan pinjam-meminjam antara Koperasi dengan pihak lain dalam hal mana pihak yang meminjam berkewajiban melunasi hutangnya setelah jangka waktu tertentu dengan jumlah bunga yang telah ditentukan". Jika seseorang menggunakan jasa kredit, maka ia akan dikenakan bunga tagihan

\section{Penggolongan Pinjaman Bermasalah}

Kegiatan penyaluran pinjaman adalah proses pembentukan asset koperasi. Pinjaman merupakan risk asset bagi koperasi karena asset koperasi itu dikuasai oleh pihak luar koperasi yaitu para anggota. Setiap koperasi menginginkan dan berusaha keras agar kualitas risk asset ini selalu sehat dalam arti produktif dan collectable (Tertagih). Namun pinjaman yang diberikan kepada para nasabah selalu ada resiko berupa pinjaman bermasalah atau dapat digolongkan sebagai pinjaman macet. Berikut ini adalah penggolongan dari pinjaman bermasalah, sebagai berikut:

a. Pinjaman yang kurang lancar

Pinjaman bisa dikatakan kurang lancar apabila ia memenuhi kriteria berikut:

1) Pengembalian pinjaman dilakukan dengan angsuran dan terdapat angsuran pokok yaitu:

a) tunggakan melampaui 1 (satu) bulan dan belum melebihi 2 (dua) bulan bagi pinjaman dengan angsuran harian dan/atau mingguan.

b) melampaui batas 3 (tiga) bulan dan belum melebihi 6 (enam) bulan bagi pinjaman yang masa angsurannya ditetapkan bulanan, 2 (dua) bulan atau 3 (tiga) bulan.

c) melampaui 6 (enam) bulan tetapi belum melebihi 12 (dua belas) bulan bagi pinjaman yang masa angsurannya ditetapkan 6 (enam) bulan atau lebih. 
2) Terdapat tunggakan bunga sebagai berikut:

a) tunggakan melampaui 1 (satu) bulan tetapi belum melebihi 3 (tiga) bulan bagi pinjaman dengan masa angsuran kurang dari 1 (satu) bulan.

b) melampaui 3 (tiga) bulan, tetapi belum melebihi 6 (enam) bulan bagi pinjaman yang masa angsurannya lebih dari 1 (satu) bulan.

3) Pengembalian pinjaman tanpa angsuran yaitu:

a) Pinjaman belun jatuh tempo

Terdapat tunggakan bunga yang melampaui 3 (tiga) bulan tetapi belum melampaui 6 (enam) bulan.

b) Pinjaman telah jatuh tempo

Pinjaman telah jatuh tempo dan belum dibayar tetapi belum melampaui 3 (tiga) bulan.

\section{Kerangka Pemikiran}

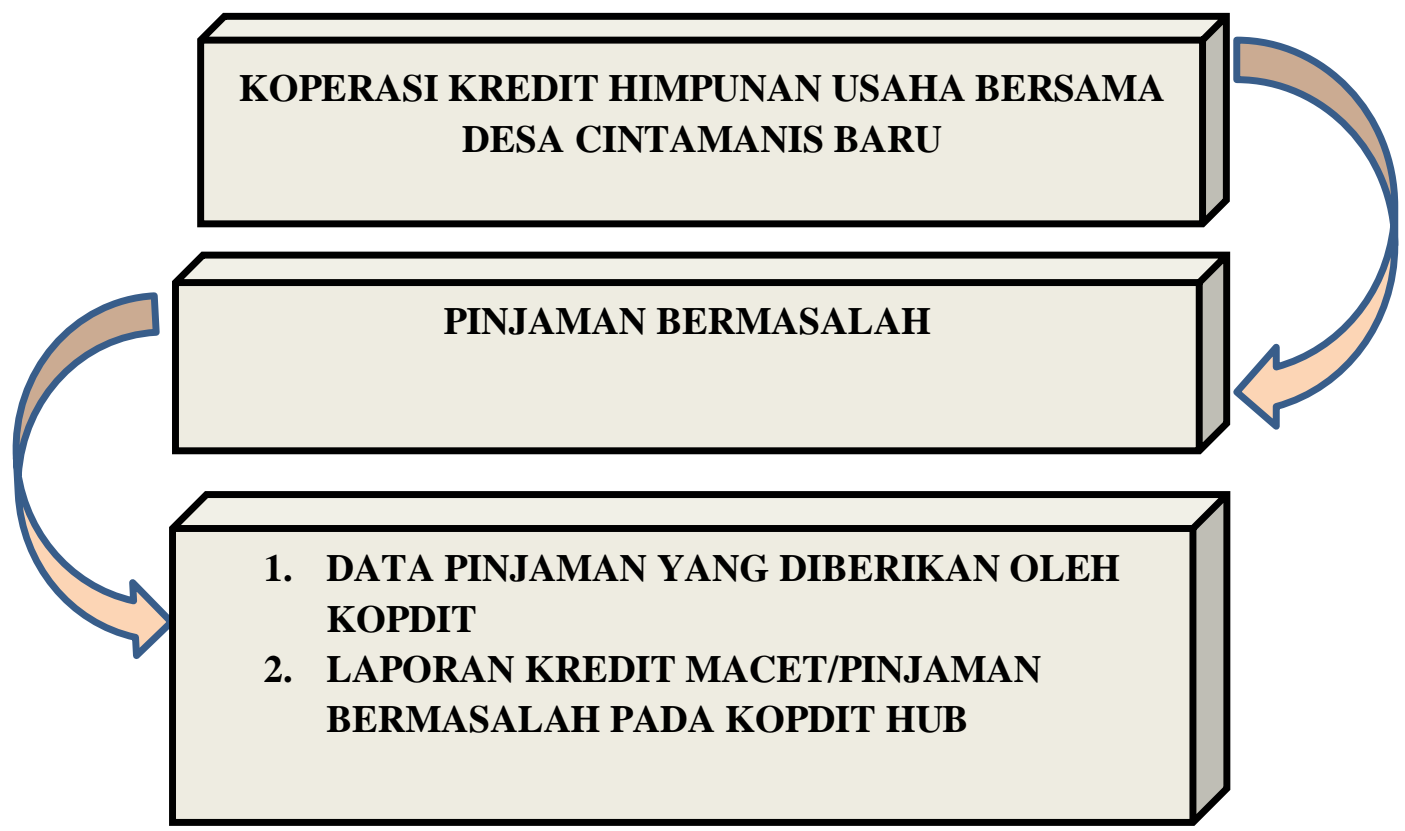

\section{METODE PENELITIAN}

Metode Penelitian Kualitatif menurut Sugiyono (2018:213) adalah metode penelitian yang berlandaskan pada filsafat, yang digunakan untuk meneliti pada kondisi ilmiah (eksperimen) dimana peneliti sebagai instrumen, teknik pengumpulan data dan dianalisis yang bersifat kualitatif lebih menekan pada makna.

Metode yang digunakan dalam penelitian ini adalah metode analisis deskiptif kualitatif yaitu pembahasan secara sistematis, faktual dan akurat mengenai suatu objek yang diteliti.

\section{Variabel Penelitian}

Menurut Sugiyono (2016:95) variabel merupakan segala sesuatu yang berbentuk apa saja yang ditetapkan oleh peneliti untuk dipelajari sehingga diperoleh informasi tentang hal tersebut kemudian ditarik kesimpulannya.

Variabel dalam penelitian ini adalah Standar Penanganan pinjaman bermasalah Pada Koperasi Kredit Himpunan Usaha Bersama Desa Cinta Manis Baru Kecamatan Air Kumbang Kabupaten Banyuasin. 


\section{Definisi Operasional Istilah}

Pengertian definisi operasional adalah penentuan konstrak atau sifat yang akan dipelajari sehingga menjadi variabel yang dapat diukur, Definisi Operasional menjelaskan cara tertentu yang digunakan untuk meneliti dan mengoprasikan konstrak, sehingga memungkinkan bagi peneliti yang lain untuk melakukan replikasi pengukuran dengan cara yang sama atau mengembangkan cara pengukuran konstrak yang lebih baik, Sugiyono (2014).

Definisi Operasional dalam penelitian ini ialah:

\section{Tabel Definisi Operasional Istilah}

\begin{tabular}{|c|c|c|}
\hline Variabel & Definisi & Indikator \\
\hline $\begin{array}{l}\text { Pinjaman } \\
\text { Bermasalah/kredit } \\
\text { macet }\end{array}$ & $\begin{array}{l}\text { Keputusan Bank indonesia } \\
\text { Nomor } 30 / 267 / \mathrm{KEP} / \mathrm{DIR} \text {. } \\
\text { Pinjaman bermasalah/kredit } \\
\text { macet terjadi jika ada } \\
\text { tunggakan angsuran pokok } \\
\text { atau bungayang telah } \\
\text { melebihi } \\
270 \text { hari, atau kerugian } \\
\text { operasional ditutup dengan } \\
\text { pinjaman baru, atau dalam hal } \\
\text { hukum atau pasar ketentuan, } \\
\text { jaminan tidak dapat dicairkan } \\
\text { pada nilai wajar. }\end{array}$ & $\begin{array}{l}\text { 1. Kurang lancar (KL) } \\
\text { Kredit yang terdapat tunggakan } \\
\text { pembayaran pokok dan atau } \\
\text { bunga yang telah melampaui } 91 \\
\text { hari s/d } 180 \text { hari. } \\
\text { 2. Diragukan (D) } \\
\text { Kredit yang terdapat tunggakan } \\
\text { angsuran pokok dan atau bunga } \\
\text { yang telah melampaui } 181 \text { hari } \\
\text { s/d } 270 \text { hari. } \\
\text { 3. Macet }(\mathrm{M}) \text { Kredit yang terdapat tunggakan } \\
\text { angsuran pokok dan atau } \\
\text { bungan melampaui } 271 \mathrm{~s} / \mathrm{d} 360 \\
\text { hari }\end{array}$ \\
\hline
\end{tabular}

\section{Populasi dan Sampel}

1) Populasi

Margono (2010:118) mengemukakan populasi merupakan seluruh data yang menjadi pusat perhatian seseorang peneliti dalam ruang lingkup dan waktu yang telah ditentukan. Populasi dalam penelitian ini adalah seluruh anggota Koperasi Kredit Himpunan Usaha Bersama Desa Cinta Manis Baru Kecamatan Air Kumbang Kabupaten Banyuasin.

2) Sampel

Margono (2010 : 121) Menyatakan bahwa sampel adalah sebagian dari populasi, sebagai contoh yang diambil dengan menggunakan cara-cara tertentu. Adapun sampel yang diambil dalam penelitian ini adalah beberapa anggota/pegawai Koperasi Kredit Himpunan Usaha Bersama Desa Cinta Manis Baru Kecamatan Air Kumbang Kabupaten Banyuasin tahun 2019/2020.

\section{Sumber data}

Beberapa jenis sumber data dalam suatu penelitian menurut Sugiyono (2016:308) adalah:

1) Data Primer

Data ini adalah sumber data yang langsung memberikan data kepada pengumpul data. 
2) Data Sekunder

Data ini yaitu sumber data yang tidak langsung memberikan data kepada pengumpul data.

Sumber data dalam penelitian ini yaitu data sekunder, data yang bukan diusahakan sendiri pengumpulannya oleh penulis, data berasal dari beberapa pihak yang terkait dengan penulisan ini.

\section{Teknik Pengumpulan Data}

Menurut Sugiyono (2016:396), ada beberapa metode pengumpulan data pada suatu penelitian, yaitu:

1) Dokumentasi

Dokumentasi yaitu catatan peristiwa yang sudah berlalu. Dokumen bisa berbentuk tulisan, gambar, atau karya monumental seseorang.

2) Studi Pustaka

Studi Pustaka yang berarti menelaah maupun mengutip langsung dari sumber tulisan lainnya yang berhubungan dengan masalah yang dapat digunakan sebagai landasan teorinya atau dengan menggunakan fasilitas atau sasaran perpustakaan untuk melengkapi data yang sudah ada. Data itu berupa:

(a) Struktur organisasi Kopdit HUB.

(b) Visi dan Misi Kopdit HUB.

(c) Deskripsi jabatan (job description).

(d) Sejara singkat Kopdit HUB.

3) Wawancara

Wawancara merupakan suatu teknik pengumpulan data yang dilakukan secara terstruktur maupun tidak terstruktur dan bisa dilakukan dengan cara tatap muka atau secara langsung maupun dengan menggunakan jaringan telpon.

\section{Teknik Analisis Data}

Menurut Sugiyono (2016:400) Penelitian deskriptif kualitatif searah dengan rumusan masalah serta pernyataan penelitian yang ditujukan untuk menjelaskan secara menyeluruh masalah yang akan diteliti.

Adapun teknik analisis data yang digunakan dalam penelitian ini adalah menggunakan analisis diskriptif kualitatif, metode ini menggambarkan pokok bahasan atau tema yang diambil serta menjelaskannya secara sistematis, dan harus menggunakan prosedur, metode atau cara tertentu agar penelitian tersebut sesuai dengan tujuan yang akan dicapai.

Adapun langkah-langkah untuk menganalisis data dalam penelitian ini adalah sebagai berikut:

1) Pengumpulan data

Pengumpulan data adalah mencari, mencatat, dan mengumpulkan semua secara objektif dan apa adanya sesuai dengan hasil observasi dan wawancara di lapangan yaitu mencatat data dan berbagai bentuk data yang ada dilapangan.

2) Reduksi data

Mereduksi data berarti merangkum, memilih hal-hal yang pokok, memfokuskan pada hal-hal yang penting, dicari tema dan polanya dan membuang hal yang tidak perlu, Sugiyono (2010:338). 
3) Pengambilan kesimpulan

Langkah ketiga dalam analisis data kualitatif menurut Miles dan Huberman yang dikutip oleh Sugiyono (2010:345) adalah penarikan kesimpulan dan verifikasi.

\section{HASIL PENELITIAN}

Selama 17 tahun dari tahun 1982 - 1999 Koperasi Kredit Himpunan Usaha Bersama masih merupakan Pra Koperasi dengan memanfaatkan tenaga purnawaktu dan pengelolaan masih dilaksanakan oleh pengurus. Pada tahun 1999 Koperasi Kredit Himpunan Usaha Bersama memperoleh pengesahan oleh pemerintah melalui Badan Hukum Nomor : 0040/BH/VI/III, 25 Mei 1999. Dengan bermodalkan badan hukum ini langkah Koperasi Kredit Himpunan Usaha Bersama semakin mantap sehingga diangkatlah seorang Manajer dan beberapa karyawan untuk melaksanakan pengelolaan harian secara penuh dan hasilnya sangat bagus. Dengan peningkatan kwalitas pelayanan dan Manajemen kehati-hatian maka kepercayaan masyarakat untuk bergabung dengan koperasi Kredit Himpunan Usaha Bersama semakin besar. Dengan semakin berkembangnya jumlah anggota yang dilayani maka sejak tahun 2007 Koperasi Kredit Himpunan Usaha Bersama menerapkan sistem komputerisasi sehingga pengelolaan data sebagian besar telah menggunakan komputer.

\section{Perkembangan Kredit Bermasalah Pada Koperasi Kredit Himpunan Usaha Bersama Desa Cintamanis Baru Kecamatan Air Kumbang Kab. Banyuasin}

\section{TABEL DAFTAR PINJAMAN ANGGOTA BULAN JANUARI - DESEMBER TAHUN 2019}

\begin{tabular}{|c|c|c|c|c|c|c|c|c|c|c|}
\hline \multirow[b]{2}{*}{ Bulan } & \multicolumn{10}{|c|}{ Data Permohonan dan Realisasi Pinjaman anggota KopDit HUB Tahun 2019} \\
\hline & Org & Permohonan & Org & $\begin{array}{c}\text { Pinjaman } \\
\text { umum }\end{array}$ & Org & $\begin{array}{c}\text { Pinjaman } \\
\text { PKPS } \\
\text { BBM } \\
\end{array}$ & Org & $\begin{array}{c}\text { Pinjaman } \\
\text { Non } \\
\text { Anggota } \\
\end{array}$ & Org & Jumlah \\
\hline Jan & 140 & 2.997.510.000 & 111 & 2.087 .510 .000 & 0 & 0 & 0 & 0 & 111 & 2.087 .510 .000 \\
\hline Feb & 141 & 2.680 .500 .000 & 122 & 2.160 .500 .000 & 0 & 0 & 0 & 0 & 122 & 2.160 .500 .000 \\
\hline Mar & 172 & 3.847 .240 .000 & 145 & 3.118 .240 .000 & 0 & 0 & 0 & 0 & 145 & 3.118 .240 .000 \\
\hline Apr & 155 & 3.831 .300 .000 & 155 & 3.831 .300 .000 & 0 & 0 & 0 & 0 & 155 & 3.831 .300 .000 \\
\hline Mei & 144 & 2.549 .180 .000 & 144 & 2.549 .180 .000 & 0 & 0 & 0 & 0 & 144 & 2.549 .180 .000 \\
\hline Jun & 74 & 1.737 .600 .000 & 74 & 1.737 .600 .000 & 0 & 0 & 0 & 0 & 74 & 1.737 .600 .000 \\
\hline Jul & 128 & 2.549 .900 .000 & 111 & 2.156 .900 .000 & 0 & 0 & 0 & 0 & 111 & 2.156 .900 .000 \\
\hline Agt & 92 & 2.830 .530 .000 & 62 & 2.049 .030 .000 & 0 & 0 & 0 & 0 & 62 & 2.049 .030 .000 \\
\hline Sept & 347 & 4.280 .602 .500 & 335 & 4.040602 .500 & 0 & 0 & 0 & 0 & 335 & 4.040602 .500 \\
\hline Okt & 717 & 1.895 .000 .000 & 146 & 1.422 .500 .000 & 0 & 0 & 0 & 0 & 146 & 1.422 .500 .000 \\
\hline Nov & 114 & 1.772 .765 .000 & 82 & 1.151 .765 .000 & 0 & 0 & 0 & 0 & 82 & 1.151 .765 .000 \\
\hline Des & 60 & 1.519 .305 .000 & 58 & 1.474 .305 .000 & 0 & 0 & 0 & 0 & 58 & 1.474 .305 .000 \\
\hline Jumlah & 1.738 & 32.491 .432 .500 & 1.545 & 27.779 .432 .500 & 0 & 0 & 0 & 0 & 1.545 & 27.779 .432 .500 \\
\hline
\end{tabular}

Sumber : Koperasi Kredit Himpunan Usaha Bersama (KopDit HUB) Tahun 2020 
Tabel Data Permohonan dan Realisasi Pinjaman anggota yang diberikan oleh Koperasi Kredit Himpunan Usaha Bersama (KopDit HUB) desa Cintamanis Baru Kecamatan Air Kumbang Kabupaten Banyuasin menunjukan bahwa pinjaman umum diberikan kepada anggota terbanyak terdapat pada bulan September dengan jumlah senilai 4.280.602.500 dan jumlah pinjaman umum yang di berikan pada tahun 2019 adalah sebesar 27.779.432.500.

\section{Laporan kredit macet/pinjaman bermasalah Koperasi Kredit Himpunan Usaha Bersama Desa Cintamanis Baru Kecamatan Air Kumbang Kab. Banyuasin}

\begin{tabular}{|l|c|c|c|}
\hline \multirow{2}{*}{ Bulan } & \multicolumn{2}{|c|}{ Jenis Tunggakan } & \multirow{2}{*}{ Jumlah } \\
\cline { 2 - 3 } & $\begin{array}{c}\text { Tunggakan } \\
<\mathbf{1 2}\end{array}$ & $\begin{array}{c}\text { Tunggakan } \\
\mathbf{> 1 2}\end{array}$ & \\
\hline Januari & 1.887 .710 .500 & 5.030 .732 .500 & 6.918 .443 .001 \\
\hline Februari & 1.910 .254 .500 & 5.342 .275 .000 & 7.252 .529 .502 \\
\hline Maret & 1.869 .355 .500 & 4.821 .312 .000 & 6.690 .667 .503 \\
\hline April & 1.925 .500 .500 & 5.204 .774 .500 & 7.130 .275 .004 \\
\hline Mei & 1.972 .305 .500 & 4.873 .543 .000 & 6.845 .848 .505 \\
\hline Juni & 2.189 .109 .500 & 6.323 .085 .000 & 8.512 .194 .506 \\
\hline Juli & 1.781 .340 .500 & 4.606 .345 .000 & 6.387 .685 .507 \\
\hline Agustus & 1.995 .970 .500 & 3.820 .043 .000 & 5.816 .013 .508 \\
\hline September & 1.730 .025 .500 & 3.488 .315 .000 & 5.218 .340 .509 \\
\hline Oktober & 1.691 .025 .500 & 4.086 .095 .000 & 5.777 .120 .510 \\
\hline November & 1.439 .120 .500 & 3.333 .470 .000 & 4.772 .590 .511 \\
\hline Desember & 1.411 .690 .500 & 2.687 .207 .500 & 4.098 .898 .012 \\
\hline
\end{tabular}

Sumber : Koperasi Kredit Himpunan Usaha Bersama (KopDit HUB) Tahun 2020

Dalam tabel dapat dilihat kredit macet/pinjaman bermasalah pada Koperasi Kredit Himpunan Usaha Bersama Desa Cintamanis Baru Kecamatan Air Kumbang Kabupaten Banyuasin terdapat dalam setiap bulan mengalami kredit macet/pinjaman bermasalah karna hal itu tidak dapat di hindari dalam usaha simpan pinjam atau perkreditan.

Standar penanganan yang berlaku bagi pinjaman yang bermasalah pada koperasi Kredit Himpunan Usaha Bersama

a) Identifikasi

b) Mengingatkan anggota lalai

c) Menarik simpanan anggota

d) Surat pemberitahuan tunggakan pinjaman

e) Surat panggilan kepada anggota lalai untuk musyawarah

f) Mendatangi rumah anggota baik sendiri maupun bersama team. 


\section{E. PEMBAHASAN}

1) Faktor-faktor yang menyebakan terjadinya kredit macet atau pinjaman bermasalah pada KopDit HUB.

Dari hasil wawancara yang penelit lakukan kepada pegawai koperasi Kredit Himpunan Usaha Bersama yang bertugas turun langsung ke lapangan ada beberapa faktor yaitu:

a) Untuk di daerah perairan yaitu petani padi penyebab kredit macet biasanya adalah karena petani gagal panen sehingga kebanyakan mereka hanya bisa membayar bunganya saja.

b) Untuk di daerah daratan ada beberapa hal yang menyebabkan kredit macet yaitu:

1) Petani Karet

Turunnya harga karet, cuaca yang tidak menentu juga bisa mengakibatkan kurangnya getah yang diperoleh oleh petani.

2) Petani Sawit

Turunnya harga Sawit, Sawit yang mengalami Trek/buah memutus selama beberapa bulan, keadaan cuaca, karna jika cuaca hujan akses jalan menjadi rusak sehingga petani sulit untuk membawa sawit menuju ke pabrik.

3) Petani Sayuran dan buah

Di Bulan-bulan tertentu yaitu bulan Februari, Maret, April biasanya curah hujan meningkat yang membuat ladang-ladang para petani banyak yang mengalami kebanjiran sehingga mengakibatkan panen semangka, cabai dan sebagainya itu gagal total sehingga petani tidak bisa melunasi atau membayar hutang-hutangnya.

\section{2) Penanganan Pinjaman bermasalah pada Koperasi Kredit Himpunan Usaha Bersama}

Berdasarkan hasil analisis pada bab ini yang didasarkan pada hasil wawancara langsung dengan manajemen Koperasi Kredit Himpunan Usaha Bersama Desa Cintamanis Baru Kecamatan Air Kumbang Kabupaten Banyuasin maka terdapat beberapa tahapan yang dilakukan untuk menangani pinjaman bermasalah, yaitu :

a) Identifikasi

Petugas lapangan mencari tahu terlebih dahulu mengapa anggota tersebut bisa lalai, sehingga petugas lapangan bisa mengantisipasi dan memberikan motivasi bagaimana jalan yang terbaik, misalnya jika biasanya anggota mengangsur $R p$ $500.000 /$ bulan, karna keadaan anggota yang seperti saat ini maka koperasi memberikan keringanan dengan hanya membayar bunganya saja dan jika keadaan sudah kembali normal atau panen angsuran akan dibayar doubel.

b) Mengingngatkan anggota

Mengingatkan anggota lalai dengan cara menelpon anggota bahwa telah jatuh tempo yang telah disepakati karna anggota yang mengalami kredit macet biasanya lupa dengan jadwal pembayaran yang telah disepakati.

c) Menarik simpanan anggota

Menarik simpanan anggota di lakukan Koperasi Kredit Himpunan Usaha Bersama jika anggota sudah benar-benar failed dan tidak bisa membayar hutangnya. 
d) Memberi surat pemberitahuan

Bagi anggota lalai yang melebihi batas 6 (enam) bulan akan diberikan surat pemberitahuan tunggakan pinjaman sebanyak 3 (tiga) kali.

1) Surat pemberitahuan yang ke-1 atau yang pertama diberikan pada minggu pertama pada saat melebihi batas 6 (enam) bulan;

2) Surat pemberitahuan yang ke-2 diberikan pada minggu ke dua pada saat melebihi batas 6 (enam) bulan dan;

3) Surat pemberitahuan yang terakhir atau yang ke-3 (tiga) diberikan pada saat melebihi batas 6 (enam) bulan.

e) Surat Panggilan

Apabila surat pemberitahuan tersebut tidak ditanggapi oleh anggota maka akan diberikan surat panggilan kepada anggota untuk datang ke kantor untuk menindak lanjuti atau musyawarah masalah pinjaman anggota tersebut.

f) Mendatangi rumah anggota

Dengan cara negosiasi datang kerumah anggota untuk bertanya mengapa belum membayar kredit yang dipinjam.

\section{F. KESIMPULAN DAN SARAN}

1) Kesimpulan

Berdasarkan hasil analisis yang telah dijelaskan pada bab sebelumnya maka dapat disimpulkan bahwa Standar Penanganan yang dilakukan koperasi Kredit Himpunan Usaha Bersama Desa Cinta Manis Baru Kecamatan Air Kumbang Kabupaten Banyuasin sudah cukup baik namun koperasi Kredit Himpunan Usaha Bersama tidak mengikuti prosedur sesuai SOM (Standar Operasional Manajemen). Tahap yang tidak ada yaitu pembinaan anggota. Padahal pembinaan anggota berfungsi sebagai pendekatan kepada anggota, hal ini dilakukan agar anggota yang mengalami kredit macet tetap mau berusaha membayar hutangnya.

2) Saran

Berdasarkan hasil penelitian, maka penulis menyarankan hal-hal yang dapat dijadikan pertimbangan sebagai berikut:

a. Berdasarkan faktor-faktor penyebab terjadinya pinjaman bermasalah/kredit macet pada Koperasi Kredit Himpunan usaha Bersama sebaiknya Koperasi Kredit Himpunan Usaha Bersama melakukan pemantauan serta pembinaan kepada anggota agar usaha para anggota dapat berjalan lancar dan tidak menghambat pada pembayaran pinjaman yang berdampak kurang baik pada koperasi Kredit Himpunan Usaha Bersama Desa Cinta Manis Baru Kecamatan Air Kumbang Kabupaten Banyuasin.

b. Standar Penanganan Pinjaman Bermasalah pada koperasi Kredit Himpunan Usaha Bersama sudah cukup baik, tetapi seharusnya Koperasi Kredit Himpunan Usaha Bersama lebih memperketat lagi dalam pemberian kredit, ini mengantisipasi agar tidak terjadi pinjaman bermasalah. Tujuan secara umum adalah untuk mengurangi jumlah anggota yang mengalami pinjaman bermasalah/kredit macet.

c. Koperasi Kredit Himpunan Usaha Bersama sebaiknya menyelesaikan pinjaman bermasalah dengan mengikuti semua tahap-tahap dalam SOM agar penyelesaian pinjaman bermasalah berjalan dengan baik dan sesuai yang diharapkan. 


\section{DAFTAR PUSTAKA}

Republik Indonesia. 1992. Undang-undang Nomor 25 Tahun 1992. Tentang Perkoperasian.

PSAK. No. 27. 2007. Koperasi Berdasarkan Jenisnya. 2007

Republik Indonesia Peraturan Mentri Koperasi Usaha Kecil dan Menengah. 2015 Nomor 12/Per/M.KUKM/2015. Tentang Pedoman Umum Akuntansi Koperasi Sektor Ril.

Republik Indonesia. (1967). Undang-undang Nomor 12 Tahun 1967. Tentang Perkoperasian.

Republik Indonesia. (1998). Undang-undang Nomor 10 Tahun 1998. Tentang Perkoperasian

Sugiyono (2018). Metode Penelitian Manajemen. Alfabeta. Bandung.

Keputusan Bank Indonesia Nomor 30/267/KEP/DIR. Tentang perkreditan.

Koperasi Kredit Himpunan Usaha Bersama. Badan Hukum Nomor : 0040/BH/Vl/III, Tahun 1999.

Margono (2010). Pengertian Populasi. 2010

Sugiyono (2010:345) Pengambilan kesimpulan.

Koperasi Kredit Himpunan Usaha Bersama. (2019). Utw-karyawan-kopdit hub, cintamanis baru. Tahun 2019. Banyuasin : Koperasi Kredit Himpunan Usaha Bersama.

Koperasi Kredit Himpunan Usaha Bersama. (2019) Laporan Data Permohonan dan Realisasi Pinjaman Anggota. 